\title{
DỨBin
}

Technological University Dublin

ARROW@TU Dublin

\section{Blockchain and insurance: a review for operations and regulation}

Richard Brophy

Technological University Dublin, richard@richardbrophy.ie

Follow this and additional works at: https://arrow.tudublin.ie/buschmarart

Part of the Insurance Commons, and the Marketing Commons

\section{Recommended Citation}

Brophy, Richard, "Blockchain and insurance: a review for operations and regulation" (2020). Articles. 162. https://arrow.tudublin.ie/buschmarart/162

This Article is brought to you for free and open access by the School of Marketing at ARROW@TU Dublin. It has been accepted for inclusion in Articles by an authorized administrator of ARROW@TU Dublin. For more information, please contact arrow.admin@tudublin.ie, aisling.coyne@tudublin.ie,gerard.connolly@tudublin.ie.

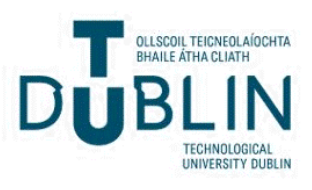




\title{
Blockchain and insurance: a review for operations and regulation
}

\author{
Richard Brophy \\ Faculty of Business and Society, University of South Wales, Pontypridd, UK and \\ Department of Marketing and Business Computing, \\ Technological University Dublin - Tallaght Campus, Tallaght, Ireland
}

Blockchain and insurance

Received 17 September 2018 Revised 25 April 2019 Accepted 30 May 2019

\begin{abstract}
Purpose - The purpose of this paper is to examine the operational and regulatory positions of the employment of Blockchain in the insurance industry. Blockchain technology has attracted wide interest from various stakeholders. Many theorists are predicting that this technology will disrupt financial services, including insurance. As stated that the development of blockchain is dependent on regulatory acceptance of this technology, it is essential to establish the current state of play with regard to the application and use of blockchain from a commercial and regulatory standpoints.

Design/methodology/approach - This review encompasses a number of approaches to view the current status of Blockchain applications. From a commercial approach, this research lists the current applications of blockchain within the insurance industry. From a regulatory point of view, the current positions of the EU and national regulatory bodies are enquired upon to establish how they are examining FinTech and Blockchain technologies within their regulatory processes.

Findings - This review illustrates a number of Blockchain applications in situ from a commercial point of view. From a regulatory setting and following a call from international and EU levels, it appears that various regulatory bodies have begun the process of formulating testing processes for FinTech applications. There are two predominant types in operation, while others are forming points of contact for advice for FinTechs and a small amount who have not begun the process at all.

Research limitations/implications - This review illustrates the current state of play of blockchain in insurance from a commercial and regulatory point of view. While this has been observational, this review pulls together information from various sources to encapsulate the regulatory positioning of evaluating FinTech and Blockchain technologies for academia, regulatory and industry audiences.

Originality/value - This review offers a central resource of information with regard to the current state of blockchain technologies in operation and regulatory approaches to this and other FinTech developments.
\end{abstract}

Keywords Regulation, Compliance, Insurance, FinTech, Blockchain, Sandbox

Paper type General review

\section{Introduction}

Blockchain technology and its development in the FinTech sector are dependent on laws and regulations which will affect how far and how fast the technology develops, and regulatory approaches will need to balance its innovative spirit against the possibility of unintentional systemic risks to the financial system (Yeoh, 2017). Scrutiny of the growth of Bitcoin and other cryptocurrencies has resulted in greater focus on the concept of distributed Blockchain databases (English et al., 2016). The enthusiasm for blockchain is summarised by Swan (2015) who states that the potential benefits of blockchain are more than just economic, they extend into the political, humanitarian, social and scientific domains and the technological capacity of Blockchain is already being harnessed by specific groups to address real-world problems.

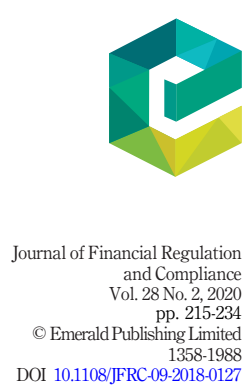


JFRC 28,2

216

Much of the published research on blockchain applications has focused on its possibilities and potential benefits. However, this has not taken into account the actual use of blockchain, or examined in detail how blockchain can improve activities. Insurance by its nature requires a significant amount of administration for managing its clients ('policyholders'), underwriting, regulatory affairs and claims processing. While published works on blockchain with an insurance theme have outlined some innovative concepts such as distributed ledger technology, smart contracts and automated processes, very few have outlined actual examples in action. As insurance is a highly regulated industry at a national and international level, regulators have a part to play in fostering and integrating with blockchain technologies so they can perform their function in the industry.

To critically apply blockchain to the insurance industry, it is crucial to establish the type of innovation blockchain brings to insurance, the functions that allow insurance companies to operate, and also to use real-time examples of blockchain in action. In addition, it is essential that we gather information from the insurance industry and from regulators regarding their attitude to the application of blockchain to this sector. While very little has been written exclusively on the insurance industry (Robson and Sekhon, 2011), this paper attempts to contextualise the main components of blockchain and its application in insurance to offer an operational and regulatory review of blockchain for academics and industry practitioners alike.

\section{Functions within insurance}

To establish where blockchain can work in insurance, it is necessary to establish the different functions and processes at work in the insurance sector. Using Porter (1985) to examine competitive advantage achieved through the various components of the value chain, allows a complete overview of the functions at work within an insurance company. However, as identified by Stabell and Fjeldstad (1998), the value chain approach may not be suitable for a service industry such as insurance, so they propose using value networks to critically analyse a service industry effectively and incorporate a customer dimension into the analysis. Using this approach and research done by Fjeldstad and Ketels (2006) on a typical insurance undertaking, they have broken down the components into three groupings, creating an insurance value network (Figure 1).

Figure 1. Insurance value network

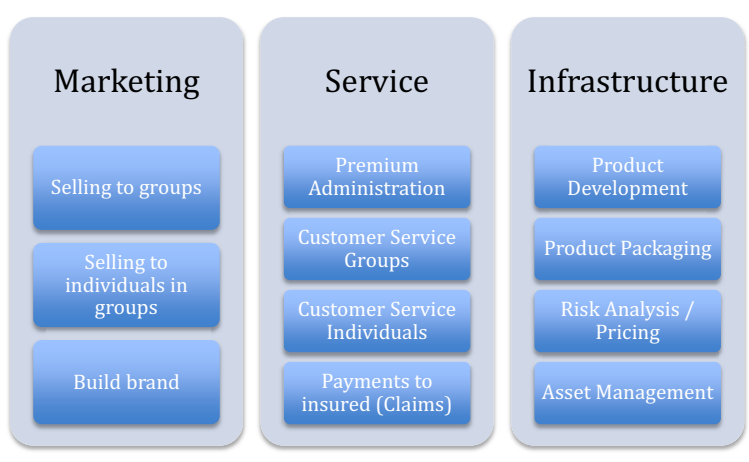

Source: Adapted from Fjeldstad and Ketels (2006) 
In breaking this down further, it is necessary to look at the components in the three groupings forming the value network. Focusing on Marketing, insurers sell through many channels, identified as distribution channels. In most cases, they do not rely on one source exclusively but operate via many approaches by selling directly to customers or using intermediaries ranging from traditional insurance brokers to branded entities and wholesaling operations (Figure 2) (Brophy, 2015).

Marketing can be carried out in various ways. Insurance companies do perform a marketing function where they promote their products and associated services. However, if they are using intermediaries, marketing efforts could be conjoined or partnered up to ensure market share growth or cross-promotional opportunities.

Consideration of the service grouping shows many of these functions are operated inhouse or outsourced to specialist firms or intermediaries. Premium administration is an essential part of an insurance operation that frequently has regulatory rules and procedures. Finance departments, usually in-house, handle the premiums of policyholders and also intermediaries selling products and collecting premiums on their behalf. Customer service can be provided in various ways, such as underwriting, providing quotations, mid-term alterations, preparing renewals and dealing with other customer queries. While insurers and some intermediaries are usually involved in this process, other insurers use processing firms to perform some, if not most, of the tasks. Making payments to insured parties who have made a claim, are an essential function of the insurance process. Depending on the size and type of claim, insurers use loss adjusters to evaluate the claim application and quantify the loss payable to the insured. Loss adjusting is often outsourced by insurance companies, with many using specialist or large firms to perform this task.

Focusing on the infrastructure grouping, you can easily see that these functions are essential for the viability and existence of the insurance company. Product development is often performed in-house. However, with the advent of different types of distribution models

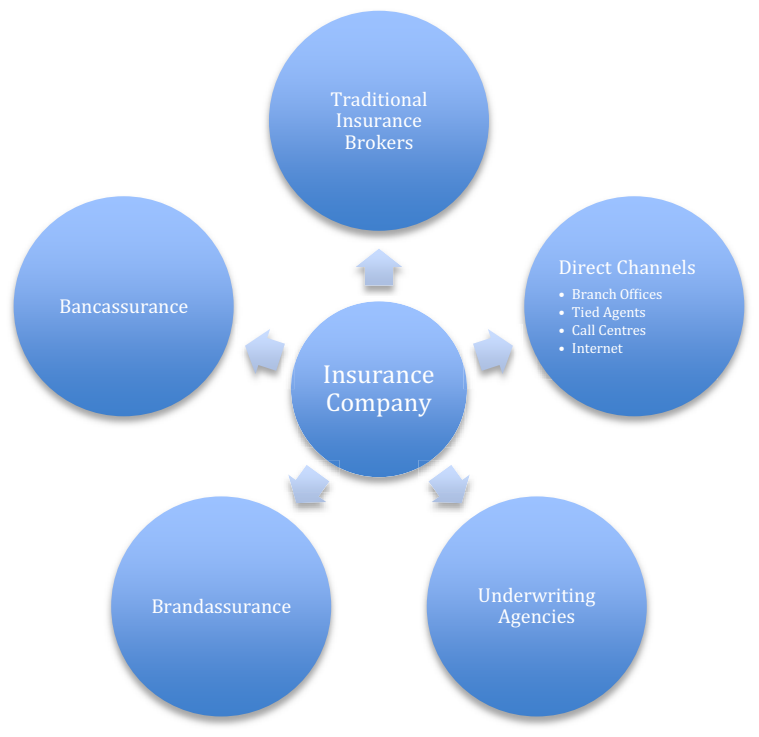

Figure 2. Distribution channels for insurance Source: Adapted from Brophy (2015) companies 
JFRC 28,2 where brands and banks are packaging insurance products, product development has become more developed, involving cross-industry partners (Brophy, 2013) (Brophy, 2015). Risk analysis/pricing is more an in-house function of the insurers, and is usually done by actuaries who set the premiums or establish the premium calculation system. Actuaries use the law of large numbers to set premiums because a loss on one policy might be compensated for by more favourable results on others (Dhaene et al., 2012). This is a highly regulated area where there have been many cross-border regulatory initiatives harmonising solvency definitions and insurance processes (i.e. the Solvency II Directive). In demonstrating the reserves held by an insurance company to protect its policyholders, Asset Management is an essential part of managing the reserves according to regulatory standards. Insurers who have not done this or ensured adequate solvency have received regulatory sanctions ranging from fines to being placed into administration (Brophy, 2014).

These groupings are strongly influenced by regulation. As identified by Brophy (2012), regulation of insurance covers solvency, processes, customer protection, how complaints are handled by a regulated entity and by an ombudsman, how products are advertised and how insurers engage in cross-border activity. Although there are various types of regulation across the EU, many regulators have united under different initiatives like Solvency II and used EU Directives to harmonise levels of cover for different types of insurance and processes.

\section{How does blockchain work for insurance? \\ Evolution of blockchain technology}

Long before the development of blockchain technologies, digital cash (or eCash) was conceptualised as a way of recording transactions, ensuring there was no double spending in the process, using electronic signatures and protecting identities (Chaum, 1983). Thirty years later, after difficulties with centralisation, anonymity, double spending and compatibility, the launch of bitcoin showed these issues had been overcome with the employment of a consensus mechanism demonstrating proof of work and ledger information shared across machines, rather than the use of a centralised mechanism (Pilkinton, 2016). Going beyond bitcoin and looking at the mechanics behind the cryptocurrency, we see that for a blockchain to exist it must have ledgers sharing information, using cryptographic proof of transactions and consensus recording of transactions across the network of ledgers sharing information (Crosby et al., 2016). The use of cryptography in bitcoin has resulted in less need for a third party to record transactions when it can be done through a system allowing ledgers to be verifiably synchronised through a consensus algorithm (Morgan, 2016). An essential part of blockchain is the use of cryptographic signatures forming an unforgeable record of transactions for any ledger record (Lemieux, 2016).

According to Iansiti and Lakhani (2017), five basic principles underlie this technology, characterised as:

(1) distributed database;

(2) peer-to-peer transmission;

(3) transparency with pseudonymity;

(4) irreversibility of records; and

(5) computational logic.

Table I characterises these terms to define the mechanics of blockchain. 
Distributed database

Peer-to-peer transmission

Transparency with pseudonymity

Irreversibility of records

Computational logic
Each part member on a blockchain has access to the entire database and its complete history. No single party controls the data or the information. Every part member can verify the records of its transaction partners directly, without the use of an intermediary

Communication occurs directly between peers instead of through a central database model. Each part member of the blockchain stores and forwards the information to all part members

Every transaction and its associated value are visible to anyone with access to the system. Each part member or user on a blockchain has a unique address that identifies it. Users can choose to remain anonymous or provide proof of identity to others. Transactions occur within the blockchain Algorithms employed in blockchain technology prevent the altering of data. Once data is entered into the part members of the blockchain they cannot be altered as they are linked to every other record entered into the chain of records Blockchain transactions can be tied to computational logic and be programmable. Part members of the blockchain can set up algorithms and rules that automate and trigger transactions between part members
Blockchain and insurance

219

Table I.

Five basic principles underlying blockchain technology

Source: Adapted from Iansiti and Lakhani (2017)

Blockchain features as highlighted by Gatteschi et al. (2018) describe some characteristic points required for an insurance blockchain to function effectively (Table II).

It is clear that blockchain offers many unique and useful features that a centralised database cannot provide for various reasons. In short, a blockchain is a sophisticated technology, but its primary function is simple: providing a distributed yet provably accurate record, or in other words, everyone can maintain a copy of a dynamically updated ledger, but all those copies remain the same, even without a central administrator or master version (Werbach, 2018).

\section{Framework for application in insurance \\ Type of innovation}

When examining how blockchain promises to innovate the insurance industry, it is important to classify what type of innovation this might be. There is universal consensus that innovation can be classified under the three general themes of:

(1) disruptive (Christensen, 1997; Markides, 2006);

(2) radical (Dewar and Dutton, 1986; Markides, 2006; Norman and Verganti, 2014); and

(3) incremental (Dewar and Dutton, 1986; Norman and Verganti, 2014).

Decentralised validation

Data redundancy

Data immutability

Trust

Transparency

Source: Adapted from Gatteschi et al. (2018) intermediaries
Network nodes perform the validation of transactions without the need for

Each network node has a local copy of the blockchain, which prevents data losses

Data stored in the blockchain cannot be modified or deleted

Cryptography enables trust between parties since a transaction that has been validated using the user's credentials cannot be repudiated

Everyone can read the blockchain and the transactions stored in it
Table II.

Blockchain characteristics for an insurance application 
JFRC 28,2

220
There are slight variations in these themes, which are described in Table III.

The definition of innovation has evolved over time. Innovation has often been considered to be either a new device or method to improve a process or procedure, often associated with technology. The concept of and term innovation is often also viewed as the application of better solutions that meet new requirements, unarticulated needs or existing market needs (Maranville, 1992).

Disruptive innovation as characterised by Christensen (1997) has been defined as innovation that dramatically disrupts a current market. Various examples of this concept have been described, in some cases conflicting with other innovation concepts. Disruptive innovation used to be considered with reference only to technologies which changed markets, but over the years the term has increasingly been applied to business model innovations, with the two areas being distinguishing from each other (Markides, 2006).

Radical innovation has been developed as a concept and term to classify a unique type of innovation. According to Norman and Verganti (2014), radical innovation changes the frame, or in other words does what we did not do before. Their research focuses on how technological and meaning driven innovation gave way to radical innovation. However, business model innovations differ from technological innovations, especially regarding their adoption and success (Markides, 2006). Within the realm of radical innovation, tacit knowledge plays an essential role in breakthrough innovation, and includes the ability of firms to form and nurture knowledge-sharing groups which may be more critical to long-

\begin{tabular}{ll}
\hline General theme & Definition \\
\hline Disruptive & $\begin{array}{l}\text { An innovation that dramatically disrupts a } \\
\text { current market (Christensen, 1997) }\end{array}$ \\
Radical & $\begin{array}{l}\text { Change of frame, i.e., doing what we did } \\
\text { not do before (Norman and Verganti, 2014) }\end{array}$
\end{tabular}

Table III.

Different types of innovation
Incremental
Otherwise known as

Business Model Innovation (Markides, 2006)

New-to-the-World Product Innovation (Markides, 2006), Breakthrough Innovation (Mascitelli, 2010), Explorative (DunlapHinkler et al., 2010)

Sustaining Innovation (Yu and Hang, 2010), Exploitative (Dunlap-Hinkler et al., 2010)

\section{Common features of peer-to-peer insurance models}

Expected benefits of peer-to-peer insurance

\section{Table IV.}

Peer-to-peer insurance $-\mathrm{a}$ definition peer-to-peer

Source Adapted from EIOPA (2017)
Policyholders pooled into peer groups

Benefits sharing scheme in case of good claims experience 'Group self-insurance'

Improving customer experience to improve loyalty

Fostering lower-risk responsible behaviours through transparency, social emulation and economic incentives

Also:

Reducing administration costs through digitised processes

Reducing distribution costs through unique selling point

Reducing the costs of insurance for customers

NO: not strictly speaking, as it does not work as a two-sided platform like other peer-to-peer models

YES: as it matches the general spirit of the sharing economy 
term competitive advantage than the transitory benefits of even the most commercially successful innovations (Mascitelli, 2010).

Another type of distinctive innovation is incremental innovation, which seeks to reach the highest form of its current technology, in contrast to radical innovation which seeks the highest form of innovation (Norman and Verganti, 2014). Consequently, radical and incremental innovation operates quite differently. Within the realm of incremental innovation, which includes sustaining innovation, (Yu and Hang, 2010) cite the example of how Dell progressed from selling computers using mail order, then call centres and eventually the internet, while HP, Compaq and IBM sold directly to customers, disrupting the marketplace having a significant impact on their existing retail channel partners. There is an association with disruptive innovation, in that incremental innovations in the form of new features, extensions, variations or complements to an existing product line, build on the dominant designs created by breakthrough innovations (Dunlap-Hinkler et al., 2010) Incremental process innovations frequently involve innovations in production efficiency (Tushman and Nadler, 1986).

In discussing what type of innovation blockchain would cause in insurance, Gatteschi et al. (2018) state that this is a disruptive technology. In critically evaluating this statement, we must look at real-time examples of blockchain in action within the insurance sector.

\section{Current applications}

Despite the evolving nature of blockchain, there are many theories on how it will change the insurance market. However, some examples of blockchain in action can demonstrate the real-time application of this technology and clarify the type of innovation it will cause in an existing market. These examples cover personal, commercial and international market scenarios.

\section{Policy underwriting}

AIG in association with Standard Chartered Bank has developed a blockchain solution for the distribution of insurance policies internationally. Using a Standard Chartered master policy, AIG can cover risks using local policies in the USA, Kenya and Singapore, using blockchain digital ledger technology (Barlyn, 2017). There are many advantages to the use of this technology. First, employing a multinational policy can take a great deal of time because of local regulatory requirements, so this system provides a lot of certainty more quickly, and second, ultimately this solution makes it cheaper in situations where there are a lot of frictional costs in chasing after things, as this system makes the process faster and more cost-effective (Ralph, 2017). It was also noted that an insurance broker was not involved in the development of this technology, which is not usually the case. A notable feature of Blockchain application in insurance was that it has the ability to include third parties in the value chain/network, such as brokers, auditors and other stakeholders, giving them a customised view of policy and payment data and documentation (Insurance Journal, 2017).

\section{Peer-to-peer insurance}

Peer-to-peer insurance as a concept is similar to other recent peer-to-peer innovations that can be found in lending. With peer-to-peer insurance, this is a risk sharing network where a group of individuals pool their premiums together to insure against a risk (Investopedia, 2018a, 2018b). Peer-to-peer insurance has evolved to demonstrate significant advantages over conventional insurance operations, including mitigating the conflict that arises between a traditional insurer and a policyholder when an insurer keeps the premiums that it 
doesn't pay out in claims. (Huckstep, 2018). How this operates comes from the following process components. First, peers have mutual control on most aspects of their coverage, such as risk evaluation and processing of payments. Second, mutual control is implemented via a voting mechanism that can be delegated to proxies. Third, in easing the burden of payments between peers, blockchain technology is used as a means of providing coverage, establishing a pool from which claims are paid from and payment of successful claims (Teambrella, 2018). Another name for this type of insurance is social insurance (Investopedia, 2018a, 2018b). A feature of some peer-to-peer insurance applications identified is one significant element where a peer or members of the network of peers decided if claims are successful or not (Teambrella, 2018). The incorporation of FinTech concepts like the crowdsourcing platform and social networking led to the peer-to-peer insurance movement (Investopedia, 2018a, 2018b). The process and concept are reminiscent of how mutual insurers operated where members pooled resources in the event of future claims. From a regulatory standpoint, not all peer-to-peer insurance applications are regulated. Some proposed peer-to-peer insurance technologies avoid using the word insurance ensuring they do not fall under the regulatory scope. However, some peer-to-peer applications are regulated under Australian (Friendsurance, 2018) and in Japanese (Ikeada, 2018) regulatory processes.

\section{Marine insurance}

Marine insurance was one of the first types of modern-day commercial insurance. It is a very complex segment of the industry as it has an international scope, numerous and varied stakeholders and precious assets that are always on the move (Stanway, 2018). Danish ship operator and dominant container transporter A.P. Moller - Maersk (Maersk) in association with consultancy firm EY, data security firm Guardtime and solution provider Microsoft, with advice provided by global insurance broker Willis Tower Watson, have tested a blockchain solution in association with insurers MS Amlin and XL Catlin for providing cargo marine insurance to the Maersk fleet. As outlined, blockchain works as a tamper-proof database that is shared and updated across a network in real time and can automatically process and settle transactions via smart contracts using computer algorithms with no need for third-party verification (Kelly, 2017). Marine insurance is one of the oldest forms of insurance and by its nature employs significant resources for administration, processing and communicating between various stakeholders (Hackett, 2017). Using this blockchain solution, Maersk will manage 1000 and support over 500,000 digital ledger transactions (Zuckerman, 2018).

\section{Travel insurance}

French insurer AXA created a brand-new insurance product covering flight delays. Called Fizzy, flyers can purchase the product to cover flight delays lasting over 2 hours (AXA, 2017). Currently in the test phase and applying to flights between Paris Charles de Gaulle and US airports, the Ethereum Blockchain is used both to record a smart contract copy of the insurance policy and also to link into global air traffic databases to match flight data to the policy. The smart contract decides whether or not a policyholder should be compensated and triggers payment of a claim (Terekhova, 2017). Within this type of product, Chubb has partnered with reinsurer Swiss Re to offer an automated flight delay cover product (Dyson, 2017). 


\section{Future theoretical applications}

Industry initiatives

Insurers are monitoring the technological evolution of blockchain from a cryptocurrency. International insurers and reinsurers have established the blockchain Insurance Industry Initiative (B3i) to explore the potential of using distributed ledger technologies within the insurance industry for the benefit of all stakeholders in the value chain (B3i, 2018). More insurers and reinsurers have recently joined B3i, making it the most significant industry organisation proponent of blockchain (Marke, 2018). The Chinese reinsurance industry has also formed its own organisation to explore and develop blockchain insurance applications (Sheehan, 2018) and has issued a white paper on future development. Some members of this organisation also belong to B3i.

\section{Smart contracts}

To understand smart contracts within blockchain technology, it is essential to view them as software rather than an actual contract or an insurance proposal form as the smart contract automates many of the activities as seen in the value network presented above and in the actual insurance examples using blockchain technology. Smart contracts are defined as selfexecuting contracts where the terms of the agreement between the buyer and seller are directly written into lines of code, and where the code and the agreements contained therein exist across a distributed, decentralised blockchain network (Investopedia, 2018a, 2018b). While the idea of smart contracts was introduced independently of blockchains, and well before bitcoin was developed, the blockchain-based cryptocurrency takes advantage of smart contracts to execute transactions, and smart contracts take advantage of Bitcoin's distributed ledger to operate with autonomy (Werbach, 2018). Simply put, this has removed the need for a central authority to oversee the transactional process, due to the software automation of the smart contract. From the above, it can be seen that smart contracts are computer programs that can be correctly executed by a network of mutually distrusting nodes, without the need for an external trusted authority (Atzei et al., 2017). The Ethereum Foundation based in Switzerland is the proponent of Ethereum, which an open source, public, Blockchain-based distributed computing platform and operating system featuring smart contract (scripting) functionality (Coindesk, 2018). As stated by the Ethereum Foundation, Ethereum is a decentralised platform that runs smart contracts: applications that run precisely as programmed without any possibility of downtime, censorship, fraud or third-party interference (Ethereum Foundation, 2018).

While policy underwriting and claims processing come from traditional paper based processes, it is evident that blockchain has the potential to innovate and radically change the insurance industry as we know it (Tasca, 2019). It is clear that the information flows from blockchain has application in covering risks that have been difficult in the past due to resource constraints, allowing to make risks programmable (i.e. agricultural risks) (Swan, 2019).

\section{Regulatory positions on blockchain}

The FinTech sector is hoping to revolutionise finance with the adoption of blockchain: distributed ledger technology is forcing global financial regulators to consider whether they need to change the rules governing markets and financial services (Jones and Price, 2016). Many regulators have examined the growth of bitcoin and blockchain technology and its potential and possible uses within financial services (Magnuson, 2018). As outlined by Yeoh (2017), while EU regulators are aware of blockchain developments, they also need to recognise that the technology is significantly outpacing the rulebook. 
JFRC 28,2

224

From an insurance point of view, blockchain insurance applications appear to be welcomed by international regulators. Blockchain possible use cases in insurance are increasing and so blockchain has a high potential, particularly in the initial stage, in commercial lines, the reinsurance business and intra-group transactions (EIOPA, 2017). The International Association of Insurance Supervisors is monitoring the growth of blockchain and smart contracts within the insurance sector. They are observing many of the elements and features of blockchain insurance applications and have raised queries concerning data ownership, solvency, transparency, application of smart contracts, etc. (IAIS, 2017). On peerto-peer insurance, EIOPA (2017) have attempted to define the concept, considering there are many versions of peer-to-peer insurance applications and type of claims procession and handling premiums. The following table outlines what elements a peer-to-peer insurer consists.

National regulators have taken an interest of the growth of blockchain technologies within the FinTech and more specifically technological innovations in the insurance industry, otherwise known InsurerTech. Many regulators in Europe have used the 'sandbox' concept to test the strength, viability and rigour of new technologies and concepts. A sandbox is a controlled testing environment where firms may launch new technologies subject to specific regulator-imposed limitations often with enhanced regulatory oversight (Rowland, 2018). From a technological point of view, a sandbox is a flexible and expressive thinking environment that supports both ad hoc and more formal analytical tasks through the use of evidence marshalling and sense-making as part of software development (Wright, et al., 2006) (Figure 3).

From a regulatory perspective, sandbox exempts certain companies or activities from regulation as a means to foster experimentation and start-up activity but is limited in time or scale and not permanent (Werbach, 2018). The sandbox approach to bring regulation into the examination of blockchain technologies for FinTech has been described as the most suitable approach (Zhao, 2018). To carry out their mandate as part of their regulatory function, many regulators are harnessing technology under the term 'RegTech'

Figure 3.

Financial regulatory Sandbox concept
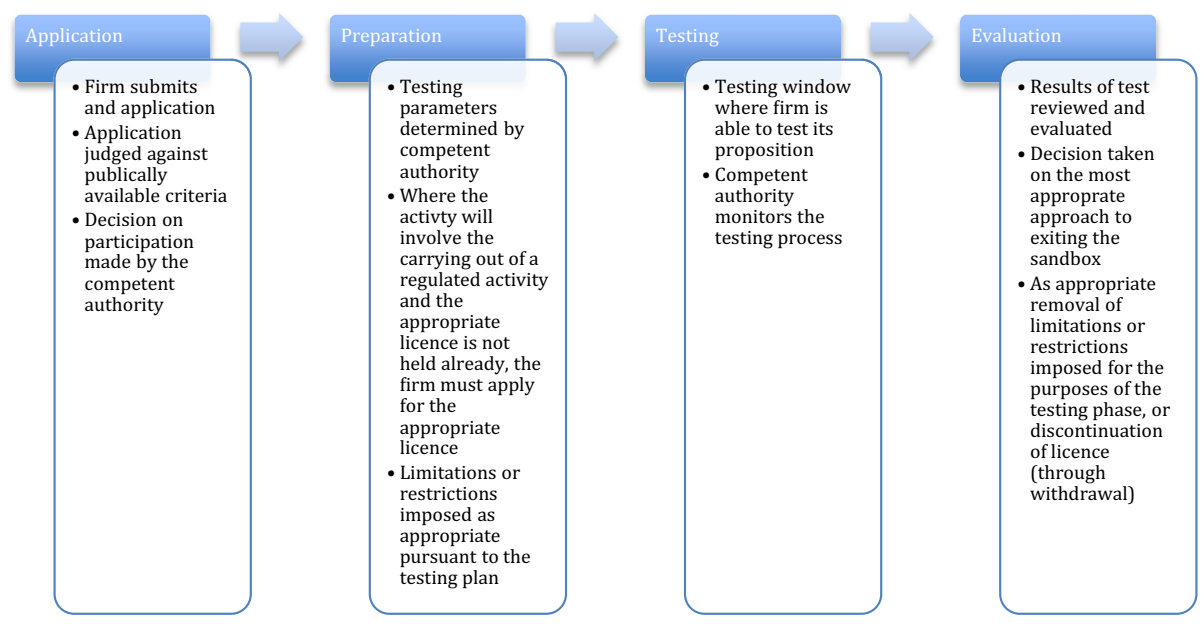

Source: Adapted from European Banking Authority (2018) 
(Finanzmarktaufsicht, 2017; Rowland, 2018). Within RegTech many of the insurer regulatory functions include the following: regulatory reporting of entities, including using smart contracts to automate and provide instant reporting and compliance on demand; customer due diligence; risk management; pattern detection; simulations for stress tests; cyber security software; and communications monitoring (Finanzmarktaufsicht, 2017). An alternative to the sandbox is the use of 'innovation hubs' by regulatory bodies. Innovation hubs provide general guidance to firms during the authorisation process, enabling such firms to gain quicker access to the market and better understand the rules and supervisory expectations, in turn providing insights to regulatory bodies on innovations within the marketplace (European Commission, 2017) (Figure 4).

Some regulators are beginning to follow the lead of the European Commission which called for a more competitive and innovative European financial sector (European Commission, 2017). National regulators of insurance markets have also begun to look beyond bitcoin and into the use of blockchain technologies and their application in insurance. For example, the Central Bank of Ireland has seen many firms call for the use of sandboxes to test new technologies, including blockchain (Central Bank of Ireland, 2017). Some regulators have voiced different opinions on the use of sandboxes. The Czech National Bank came out against broad rules for sandboxes in response the European Commission paper (Czech National Bank, 2017), while the French authorities have called for greater clarity and definition around the use of sandboxes in FinTech development (ACPR, 2017).

There are various types and regulatory uses of sandboxes. The Danish, Dutch and British regulatory bodies have implemented their FinTech sandbox, as have the Italian authorities, specifically for blockchain and insurance applications. The Irish, Hungarians, Latvians, Poles and Swedes are opting for an innovation hub model, which operates somewhat differently to a sandbox as regards definition, duration and purpose. Countries

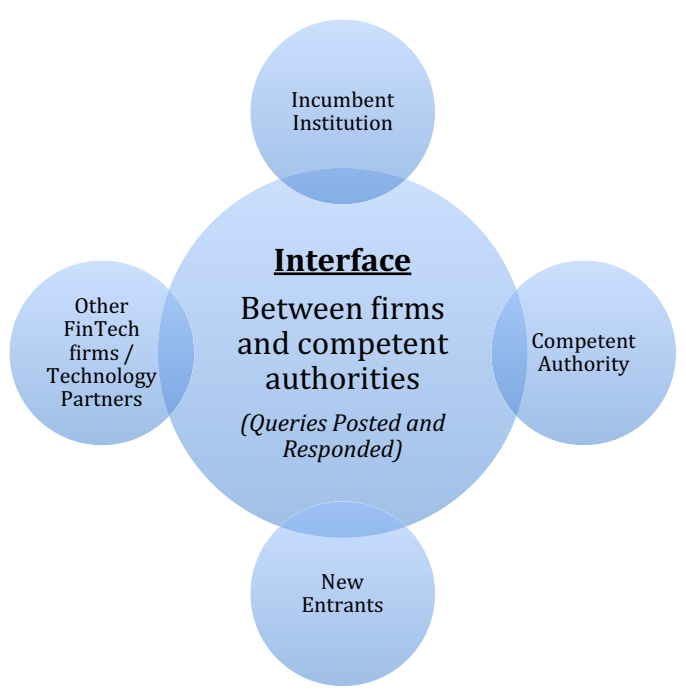

Source: Adapted from European Banking Authority (2018)
Figure 4.

Financial regulatory innovation hub concept 
JFRC 28,2

226

without a sandbox or innovation hub have begun discussing with stakeholders where they see blockchain assisting in financial services; however, they are at different stages. Some regulatory authorities have also created points on contact in the absence of either a sandbox or innovation hub model. This appears to be a temporary solution while considering the different test models. In looking across Europe (using the EIOPA voting and non-voting member list), and reviewing regulatory positions on FinTech testing models, regulators are using innovation hubs over other types of evaluation models to encourage FinTech development (see Figure 5 and Appendix). Some regulatory authorities have not begun the process of looking at ways of encouraging FinTech development. Australia is the only financial regulatory environment operating a sandbox and innovation hub simultaneously for new technologies in financial services (Investment News New Zealand, 2017).

\section{Discussion and further research}

This paper has aimed to contextualise the impact of blockchain using real-time examples of the application, to assess regulatory adoption of the technology and to establish how blockchain can affect insurers using the value chain concept to chart its future direction. As with the value chain, the flow of information determines the success or competitive advantage achieved with the application. Over 30 years ago, Porter and Millar (1985) stated that the information revolution affects competition in three ways, by:

(1) changing industry structure and, in so doing, altering the rules of competition;

(2) creating competitive advantage by giving companies new ways to outperform their rivals; and

(3) producing entire new businesses, often from within a company's existing operations.

Improvements in the flow of information generated by blockchain applications in insurance result in greater efficiencies. It is clear from the impact of bitcoin and other cryptocurrencies that blockchain has many possibilities in financial services, FinTech and especially in insurance. The involvement of groups of insurers and technology regulators' initiatives will result in this form of handling information changing the industry structure and, in doing so, altering the rules of competition from an operational and process perspective. A lot of the literature has focused on the

Figure 5.

Use of different FinTech regulatory assessment models across Europe

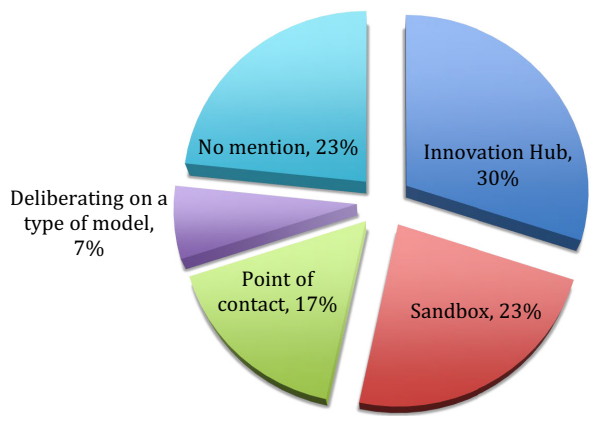

Source: Using EIOPA voting and non-voting members list 
possibilities and benefits of the use of blockchain in financial services. This research has focused on the potential and realisable benefits of blockchain, but there has been little focus on the actual use of blockchain technologies in insurance, and also where regulators stand on blockchain and its application in insurance, which is the objective of this article. As stated by Yeoh (2017), laws and regulations will affect how far and how fast the technology develops, and regulatory approaches will need to balance its innovative spirit against the possibility of unintentional systemic risks to the financial system. Therefore, to ensure blockchain has a realistic chance of implementation within the insurance industry, it is vital to examine real-life examples to ensure validity and viability.

The insurance value network was used to highlight the various functions of an insurance company and so establish the components of an insurer to critically evaluate where blockchain can work. The value network models transaction services (such as insurance) where firms create value by providing services that support exchange within a network of nodes, which can be people, organisations or physical locations (Fjeldstad and Ketels, 2006). Examination of the three groupings and comparison with current blockchain applications, shows that the Service and Infrastructure group functions are affected by the use of blockchain technology, more specifically the use of smart contracts. Consideration of the examples of blockchain in action, shows smart contracts are employed to perform all the functions within the service grouping, and some functions within infrastructure. In practice, the use of loss adjusters appointed by an insurer will be reduced significantly, with the smart contract deciding if a claim is admissible and worthy of payment. Insurer regulators also recognise the potential benefits of blockchain applications within the industry. It is becoming more common for regulators to use this technology to perform their functions more effectively, automating processes that can involve a significant amount of human resources and allowing analysis regulators make decisions and take action. Within the insurance value network, regulation covers the three groupings, with a significant focus on service and infrastructure, ensuring solvency, prudential supervision, consumer protection and service provision.

Examination of the Marketing grouping of the insurance value network, in light of insurer involvement in blockchain development and the example of policy underwriting, shows that there is less reliance on insurance brokers for the development of this technology. Insurance intermediaries (including brokers) have traditionally brought business to insurers, but the role of intermediaries is changing in a blockchain environment. Another intermediary is the loss adjuster who is independent of the insurer and decides if a claim is admissible or not. Using smart contracts will reduce the need for loss adjusters, beginning a form of disintermediation.

As for the type of innovation, blockchain is revolutionising the information flow within the industry. While the technology itself is dramatically changing how things are done, pushing the boundaries in insurance operations and how they are performed, the type of innovation may not be completely disruptive. It is clear from the literature that disruptive technology has undergone a reclassification since it first appeared in 1997. Disruptive business model change is another area gaining attention with the advent of technologies altering how business is conducted. Some functions that are dependent on intermediaries such as loss adjusters and insurance brokers, might be at risk from blockchain. As this is a technological and business model change, the most appropriate innovation term would be 'radical', for many reasons. The blockchain is changing the way insurance is performed operationally, or applying the analogy of 
JFRC 28,2

Norman and Verganti (2014), blockchain is changing the way things are done in insurance. Citing the travel disruption product, the use of blockchain is bringing newto-the-world product innovation to the marketplace (Markides, 2006). blockchain, while in its infancy within the insurance industry, is being employed in an explorative fashion (Mascitelli, 2010) to evaluate its suitability within an existing industry. A notable exception to this is peer-to-peer insurance applications where there is a definite and demonstrated case of disruptive technology in action, changing how cover operates and purchased (Huckstep, 2018). While blockchain brings a new way of handling information, it is vital that blockchain development groups (including industry and regulators) do not hamper its development and in doing so move blockchain to an incremental type of innovation, capping its potential.

Insurance is a heavily regulated industry and, in many cases, has indirect or direct government involvement (Aftalión, 2018). Yeoh (2017) has stated that laws and regulatory approaches could impact on how far and fast blockchain can be accelerated in the industry. Regulators and industry are indeed looking at blockchain critically and for use within the insurance industry. Regulators understand the benefits of blockchain within the insurance industry and have implemented processes to stimulate application testing to ensure that regulation can work with the innovative nature of this technology. The majority of EU regulators are employing sandboxes or innovation hubs to evaluate the technology. Other regulators are looking at developing their own evaluation process to critically test blockchain while also ensuring that regulation does not stifle innovation.

As acknowledged earlier, a lot has been written about blockchain, but there are very few examples of the technology in action. The three examples discussed above were used in a critical examination of the technology in action alongside industry and regulatory views. It is clear that blockchain remains a target for development within the industry where insurers and regulators are well disposed to the concept and technology in changing how insurers perform. In bringing the stakeholders together and looking at the economics of information sharing, a decentralised consensus (where blockchain is in effect) changes the information environment, offering a low cost, tamper proof algorithmic executions, and consequently enlarge the contracting space and facilitate the creation of smart contracts (Cong and He, 2019). A proposed approach of blockchain application within the motor insurance illustrates how this technology can change from reactionary after the event coverage to real-time/on demand operation of covering the policyholder (Lamberti, et al., 2018). In looking at other applications, for example in covering Agricultural risks (Gatteschi, et al., 2018), blockchain has the potential to revolutionise the operations of the industry. Breaking this down further, it changes how claims are assessed and paid, and how prudential supervision (especially solvency) of carriers needs to be changed to take account of improvements in providing cover to policyholders.

From a managerial perspective, while there are many stakeholders at the blockchain table, intermediaries and loss adjusters are not taking part to the same extent as insurers, reinsurers and regulators. It is evident that blockchain will affect the intermediaries of the insurance industry. Loss adjusters and other intermediaries should take part in blockchain, using their expertise to design business models and concepts to harness the potential of this technology. Except for marine insurance, there is very little evidence of loss adjusters or intermediaries being involved in the application or design of blockchain-powered business models. 


\section{References}

ACPR (2017), "European commission's public consultation on FinTech: a more competitive and innovative European financial sector. joint answer from banque de France and autorité de contrôle prudentiel et de résolution (ACPR)", available at: https://acpr.banque-france.fr/ sites/default/files/media/2017/09/28/20170615_reponse_consultation_europe.pdf (accessed 16 July 2018).

Aftalión, T. (2018), An Agricultural Insurance Protocol in the Blockchain, available at: http://tomas. aftalion.org/ (accessed 23 November 2018).

Atzei, N., Bartoletti, M. and Cimoli, T. (2017), "A survey of attacks on ethereum smart contracts", in: Principles of Security and Trust, Springer, Berlin, pp. 164-186.

AXA (2017), "AXA goes blockchain with fizzy”, available at: www.axa.com/en/newsroom/news/axagoes-blockchain-with-fizzy (accessed 9 July 2018).

B3i (2018), “About Us”, available at: https://b3i.tech.about-us.html (accessed 23 July 2018).

Barlyn, S. (2017), "AIG teams with IBM to use blockchain for 'smart' insurance policy”, available at: www.reuters.com/article/us-aig-blockchain-insurance/aig-teams-with-ibm-to-use-blockchain-forsmart-insurance-policy-idUSKBN1953CD (accessed 9 July 2018).

Brophy, R. (2012), "Development of insurance regulation in Ireland", Journal of Financial Regulation and Compliance, Vol. 20 No. 3, pp. 248-263.

Brophy, R. (2013), "Bancassurance: an insurance concept from a Irish perspective”, Journal of Financial Regulation and Compliance, Vol. 21 No. 4, pp. 319-333.

Brophy, R. (2014), "Rebrand in crisis: how liberty came to Ireland", Journal of Strategic Marketing, Vol. 22 No. 2, pp. 93-103.

Brophy, R. (2015), "A collection of insurance brands: the story of RSA in Ireland", Cogent Business and Management, Vol. 2 No. 1.

Central Bank of Ireland (2017), "Discussion paper 7 - digitalisation and consumer protection code", available at: https://centralbank.ie/publication/discussion-papers/discussion-paper7 -digitalisation-and-consumer-protection-code (accessed 16 July 2018).

Chaum, D. (1983), "Blind signatures and untraceable payments", in Crypto '82, Plenum Press, New York, NY, pp. 199-203.

Christensen, C.M. (1997), The Innovator's Dilemma: When New Technologies Cause Great Firms to Fail, Harvard Business School, Boston.

Coindesk (2018), "What is Ethereum", available at: www.coindesk.com/information/what-is-ethereum/ (accessed 16 July 2018).

Cong, L. and He, Z. (2019), "Blockchain disruption and smart contracts", The Review of Financial Studies, Vol. 32 No. 5, pp. 1754-1797.

Crosby, M., Pattanayak, P., Verma, S. and Kalyanaraman, V. (2016), "Blockchain technology: beyond bitcoin", Applied Innovation Review, No. 2, pp. 6-10.

Czech National Bank 2017, "Position of the Czech national bank to the selected questions of the commission consultation", available at: www.cnb.cz/miranda2/export/sites/www.cnb.cz/en/ supervision_financial_market/legislation/cnb_opinions/download/2017_fintech_consultation_ document_cnb_opinion.pdf (accessed 16 July 2018).

Dewar, R. and Dutton, J. (1986), "The adoption of radical and incremental innovations: an empirical analysis", Management Science, Vol. 32 No. 11, pp. 1422-1433.

Dhaene, J., et al., (2002), "The concept of comonotonicity in actuarial science and finance: theory", Insurance: Mathematics and Economics, Vol. 31 No. 1, pp. 3-33.

Dunlap-Hinkler, D., Kotabe, M. and Mudambi, R. (2010), "A story of breakthrough versus incremental innovation: corporate entrepreneurship in the global pharmaceutical industry", Strategic Entrepreneurship Journal, Vol. 4 No. 2, pp. 106-127. 
JFRC 28,2

Dyson, B. (2017), "Chubb teams up with swiss re to launch flight delay cover", available at: www. insurancetimes.co.uk/chubb-teams-up-with-swiss-re-to-launch-flight-delay-cover/1424944.article (accessed 9 July 2018).

EIOPA (2017), EIOPA InsurTech Roundtable - How Technology and Data Are Reshaping the Insurance Landscape, s.l, EIOPA, Frankfurt.

English, M., Auer, S. and Domingue, J. (2016), Block Chain Technologies and the Semantic Web: A Framework for Symbiotic Development, University of Bonn, Bonn, pp. 47-61.

Ethereum Foundation (2018), "Ethereum project”, available at: www.ethereum.org/ (accessed 16 July 2018).

European Banking Authority (2018), EBA Industry Roundtable: regulatory Sandboxes and Innovation Hubs, EBA, London.

European Commission (2017), FinTech: A More Competitive and Innovative European Financial Sector, European Commission, Brussels.

Finanzmarktaufsicht (2017), "FMA focus: RegTech - using innovative technologie to optimise regulatory and supervisory processes", available at: www.fma.gv.at/download.php?d=3115 (accessed 16 July 2018).

Fjeldstad, Ø. and Ketels, C. (2006), "Competitive advantage and the value network configuration making decisions at a Swedish life insurance company. Long range planning”, Band, Vol. 39, pp. 109-131.

Friendsurance (2018), “Australia's first peer-to-peer insurance”, available at: www.friendsurance.com. $\mathrm{au} /($ accessed 28 November 2018).

Gatteschi, V., Lamberti, F., Demartini, C., Pranteda, C. and Santamaría, V. (2018), "Blockchain and smart contracts for insurance: is the technology mature enough?”, Future Internet, Vol. 10 No. 2, p. 20.

Hackett, R. (2017), "Maersk and Microsoft tested a blockchain for shipping insurance", available at: http://fortune.com/2017/09/05/maersk-blockchain-insurance/ (accessed 9 July 2018).

Huckstep, R. (2018), "Introducing the third wave of peer-to-peer insurance", available at: www.thedigital-insurer.com/blog/insurtech-teambrella-and-the-third-wave-of-peer-to-peer-insurance/ (accessed 28 November 2018).

IAIS (2017), FinTech Developments in the Insurance Industry, s.l, International Association of Insurance Supervisors, Basel.

Iansiti, M. and Lakhani, K. (2017), "The truth about blockchain", Harvard Business Review, Vol. 95 No. 1, pp. 118-127, Issue January - February.

Ikeada, M. (2018), "Just in case gets approval from regulator for P2P insurance, raises $\$ 1.4 \mathrm{M}$ pre-series A", available at: https://thebridge.jp/en/2018/06/justincase-announces-official-launch (accessed 28 November 2018).

Insurance Journal (2017), "AIG 'smart' policy uses blockchain to manage international coverage for bank", available at: www.insurancejournal.com/news/national/2017/06/15/454457.htm (accessed 9 July 2018).

Investment News New Zealand (2017), “Aussie regulator plays nice with fintechs (but it's lonely in the sandbox)", Investment News New Zealand, 46.

Investopedia (2018a), "Peer-to-peer insurance", available at: www.investopedia.com/terms/p/ peertopeer-p2p-insurance.asp (accessed 28 November 2018).

Investopedia (2018b), "Smart contracts", available at: www.investopedia.com/terms/s/smart-contracts. asp (accessed 16 July 2018).

Jones, H. and Price, M. (2016), "Blockchain sends banking regulators back to basics", available at: www.reuters.com/article/us-finance-summit-blockchain-idUSKCNOYB13A (accessed 9 July 2018). 
Kelly, J. (2017), "EY teams up with Maersk, Microsoft on blockchain-based marine insurance", available at: www.reuters.com/article/us-blockchain-insurance-marine/ey-teams-up-withmaersk-microsoft-on-blockchain-based-marine-insurance-idUSKCN1BG3B6 (accessed 9 July 2017).

Lamberti, F., Gatteschi, V., Demartini, C., Pelissier, M., Gomez, A. and Santamaria, V. (2018), "Blockchains can work for car insurance: using smart contracts and sensors to provide ondemand coverage", IEEE Consumer Electronics Magazine, July, Vol. 7 No. 4, pp. 72-81.

Lemieux, V. (2016), "Trusting records: is blockchain technology the answer?", Records Management Journal, Vol. 26 No. 2, pp. 110-139.

Magnuson, W.J. (2018), "Financial regulation in the bitcoin era", Stanford Journal of Law, Business, and Finance, Vol. 23 No. 2, pp. 2-58.

Maranville, S. (1992), "Entrepreneurship in the business curriculum”, Journal of Education for Business, Vol. 68 No. 1, pp. 27-30.

Marke, K. (2018), "Blockchain is tech evolution that will create re/insurance revolution: B3i's marke", available at: www.insurancejournal.com/news/international/2018/07/11/494638.htm (accessed 23 July 2018).

Markides, C. (2006), "Disruptive innovation: in need of better theory", Journal of Product Innovation Management, Vol. 23 No. 1, pp. 19-25.

Mascitelli, R. (2010), "From experience: harnessing tacit knowledge to achieve breakthrough innovation", Journal of Product Innovation Management, Vol. 17 No. 3, pp. 179-193.

Morgan, R. (2016), "It's all about the blockchain: amid the hoopla over bitcoin and other virtual currencies, it's the underlying documentation platform that's revolutionizing transactions", $A B A$ Banking Journal, Vol. 108 No. 2, p. 51.

Norman, D. and Verganti, R. (2014), "Incremental and radical innovation: design research vs technology and meaning change", Design Issues, Vol. 30 No. 1, pp. 78-96.

Pilkinton, M. (2016), "Blockchain technology: principles and applications", in Research Handbook on Digital Transformations, Edward Elgar Publishing, Cheltenham, p. 225.

Porter, M. (1985), Competitive Advantage, The Free Press, New York, NY.

Porter, M. and Millar, V. (1985), "How information gives you competitive advantage", Harvard Business Review, July.

Ralph, O. (2017), “AIG sets up blockchain policy for standard chartered”, available at: www.ft.com/ content/03ea1b88-511b-11e7-a1f2-db19572361bb (accessed 9 July 2018).

Robson, J. and Sekhon, Y. (2011), "Addressing the research needs of the insurance sector", International Journal of Bank Marketing, Vol. 29 No. 7, pp. 512-516.

Rowland, D. (2018), Innovation and Technology in Financial Services: A Regulatory Perspective, Central Bank of Ireland, Cork.

Sheehan, M. (2018), "Hannover re joins new Chinese reinsurance blockchain initiative", Reinsurance News, Vol. 29, pp. 6.

Stabell, C. and Fjeldstad, Ø.D. (1998), "Configuring value for competitive advantage: on chains, shops, and networks", Strategic Management Journal, Vol. 19 No. 5, pp. 413-437.

Stanway, H. (2018), "Blockchain - from theoretical to authenticated", Irish Broker, Vol. 35 No. 7, pp. 46-47. July.

Swan, M. (2015), Blockchain: Blueprint for a New Economy, O’Reilly Media, Sebastopol (CA).

Swan, M., et al. (2019), "Blockchain theory of programmable risk: black swan smart contracts", in Swan, M. (Ed.), Hrsg. Blockchain Economics: Implications of Distributed Ledgers-Markets, Communications Networks, and Algorithmic Reality, Scientific World, London, pp. 171-194.

Tasca, P. (2019), "Insurance under the blockchain paradigm", in T.H. and B.R., Hrsg. Business Transformation through Blockchain, Palgrave Macmillan, Cham, pp. 273-285. 
Teambrella (2018), "Whitepaper - teambrella: a peer-to-peer coverage system (version 2.2)", available at: https://teambrella.com/WhitePaper.pdf (accessed 28 November 2018).

Terekhova, M. (2017), “AXA turns to smart contracts for flight-delay insurance”, available at: http://uk. businessinsider.com/axa-turns-to-smart-contracts-for-flight-delay-insurance-2017-9?r=US\& $\mathrm{IR}=\mathrm{T}$ (accessed 9 July 2018).

Tushman, M. and Nadler, D. (1986), "Organizing for innovation”, California Management Review, Vol. 28 No. 3, pp. 74-92.

Werbach, K. (2018), “Trust, but verify: why the blockchain needs the law", Berkeley Technology Law Journal, Band, Vol. 32.

Wright, W., Schroh, D., Proulx, P., Skaburskis, A. and Cort, B. (2006), The Sandbox for Analysis: concepts and Methods, Proceedings of the SIGCHI conference on Human Factors in computing systems, ACM, pp. 801-810, s.1., s.n.

Yeoh, P. (2017), "Regulatory issues in blockchain technology", Journal of Financial Regulation and Compliance, Vol. 25 No. 2, pp. 196-208.

Yu, D. and Hang, C. (2010), "A reflective review of disruptive innovation theory", International Journal of Management Reviews, Vol. 12 No. 4, pp. 435-452.

Zhao, W. (2018), “EU, US lawmakers tout 'sandbox' apprach for blockchain development”, available at: www.coindesk.com/us-eu-lawmakers-tout-sandbox-approach-for-blockchaindevelopment/ (accessed 16 July 2018).

Zuckerman, M. (2018), "Logistics giant Maersk starts using blockchain platform for maritime insurance", available at: https://cointelegraph.com/news/logistics-giant-maersk-starts-usingblockchain-platform-for-maritime-insurance (accessed 9 July 2018). 
Appendix

\begin{tabular}{|c|c|c|}
\hline $\begin{array}{l}\text { EU member } \\
\text { states }\end{array}$ & Insurance regulatory body & $\begin{array}{l}\text { FinTech testing } \\
\text { process }\end{array}$ \\
\hline ustria & FMA - Finanzmarktaufsicht (Financial Market Authority) & Point of contact \\
\hline Belgium & $\begin{array}{l}\text { Autorité des services et marchés financiers - FSMA (Financial } \\
\text { Services and Markets Authority) }\end{array}$ & Point of contact \\
\hline Bulgaria & $\begin{array}{l}\text { Комисия за Финансов Надзор (Financial Supervision } \\
\text { Commission) }\end{array}$ & No mention \\
\hline Croatia & Croatian Financial Services Supervisory Agency & No mention \\
\hline Cyprus & 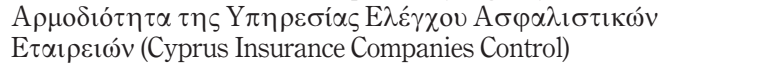 & Innovation Hub \\
\hline ech Republic & CNB - Ceska Narodni Banka (Czech National Bank) & Deliberating \\
\hline anmo & FSA - Finanstilsynet (Danish FSA) & Sandbox \\
\hline Estonia & Finantsinspektsioon (Estonia Financial Supervision Authority) & No mention \\
\hline Finland & $\begin{array}{l}\text { FIN-FSA - Finanssivalvonta (Finnish Financial Supervisory } \\
\text { Authority) }\end{array}$ & Point of contact \\
\hline France & $\begin{array}{l}\text { ACPR - Autorité de Contrôle Prudentiel et de Résolution } \\
\text { (Prudential Control Authority) }\end{array}$ & Innovation Hub \\
\hline Germany & $\begin{array}{l}\text { BaFin - Bundesanstalt fÜr Finanzdienstleistungsaufsicht (Federal } \\
\text { Financial Supervisory Authority) }\end{array}$ & Point of contact \\
\hline Greece & 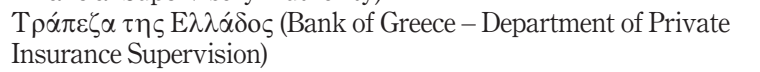 & No $m$ \\
\hline ungary & MNB - The Central Bank of Hungary & Innor \\
\hline Ireland & ntral Bank of Ireland & Innovation Hub \\
\hline Italy & IVASS - Istituto per la Vigilanza sulle assicurazioni & Sandbox \\
\hline Latvia & $\begin{array}{l}\text { FCMC - Finanšu un Kapitāla Tirgus Komisija (Financial Capital } \\
\text { Market Commission) }\end{array}$ & Innovation Hub \\
\hline Lithuania & Lietuvos Bankas (Bank of Lithuania) & Sandbox \\
\hline Luxembourg & & Innovation Hub \\
\hline Malta & MFSA - Malta Fin & Sandbox \\
\hline The Netherlands & DNB - De Nederlandsche Bank (National Bank of Netherlands) & Sandbox \\
\hline Poland & $\begin{array}{l}\text { KNF - Komisja Nadzoru Finansowego (Financial Supervision } \\
\text { Authority) }\end{array}$ & Innovation Hub \\
\hline Portu & Autoridade De Supervisao De Seguros E De Fundos De Pensoes & f conta \\
\hline & Anthority (Acf & ntion \\
\hline Slovakia & NBS - Narodna Banka Slovenska (National Bank of Slovakia) & No mention \\
\hline Slovenia & $\begin{array}{l}\text { AZN - Agencija za Zavarovalni Nadzor (Insurance Supervision } \\
\text { Agency) }\end{array}$ & No mention \\
\hline Spain & Dirección General de Seguros y Fondos de Pensiones & Sandbox \\
\hline Sweder & FI - Finansinspektionen (Financial Supervisory Author & Innovation $\mathrm{Hz}$ \\
\hline UK & Prudential Regulation Authority \& Financial Conduct Authority & Sandbox \\
\hline \multicolumn{3}{|l|}{ EEA Cou } \\
\hline & v) & \\
\hline Norway & 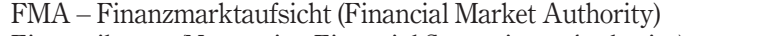 & Innovation \\
\hline Norway & Finanstilsynet (Norwegian Financial Supervisory Authority) & Deliberating \\
\hline
\end{tabular}

Blockchain
and insurance 


\section{About the author}

Richard Brophy is a Member of the Department of Marketing and Business Computing of the Technological University Dublin - Tallaght Campus. Brophy lecturers on a range of marketing, business and communication modules. With an industry background in insurance, Richard has an academic interest in the retailing of financial services on aspects of marketing and regulation and has written for various marketing and regulatory journals. Richard holds a Bachelor of Arts, Business Studies degree from the University of Glamorgan, a Masters of Business Studies degree from Dublin City University and a Graduate Diploma in Financial Planning from University College Dublin. He also holds a number of professional marketing and financial services qualifications including the Certified Financial Planner ${ }^{\mathrm{TM}}$ designation and the Advanced Diploma in Insurance from the Chartered Insurance Institute (UK). In late 2015, Richard earned his $\mathrm{PhD}$ from the University of South Wales, where his research focused on financial services marketing. Richard Brophy can be contacted at: richard@richardbrophy.ie

For instructions on how to order reprints of this article, please visit our website: www.emeraldgrouppublishing.com/licensing/reprints.htm Or contact us for further details: permissions@emeraldinsight.com 